\title{
RE-ASSESSMENT OF "CLAW-BACK" CLAUSES IN THE ENFORCEMENT OF HUMAN AND PEOPLES' RIGHTS IN AFRICA
}

\author{
William Edward Adjei* \\ Ghana Institute of Management and Public Administration, Accra, Ghana \\ E-mail:weadjei@yahoo.com
}

(Received: August 2019; Accepted: October 2019; Published: November 2019)

\begin{abstract}
One of the continuing problems, which had faced the African Charter, is many of its substantive provisions that are raven with qualifications without reasonable justification. These rights guaranteed under the Charter are subject to "claw-back" clauses that are introduced by governments and public authorities thereby undermining their citizen's basic constitutional rights of securing fundamental freedoms. They are those rights that impose negative duty on the state and are meant to promote the values of pluralism, equality and human dignity, which should be enjoyed free from state interference. It is in the interference of these rights that commentators have frequently criticized the African Charter for rendering its protective mandate meaningless and unenforceable. With hindsight, it is evident that the foregoing critique levelled against the "claw-back" clauses under Charter is justified, as they have a chilling effect on the exercise of human and peoples' rights on the African continent. Such condition has produced intense academic discussion on the interpretation and implications of the rights and freedoms enshrined in the Charter. None the less, the scope and the significance of the legal measures adopted by the African Commission have minimized the impact of the clauses affected considerably. Accordingly, a strong principle of interpretation adopted by the Commission has contributed to shaping the Charter's legal structure in harmony with international human rights law standards.
\end{abstract}

Keywords: protection, promotion, human rights, peoples' rights, national laws, democracy, participation, African Commission, liberties and freedoms, interpretation and enforcement mechanisms.

\section{Introduction}

The effect of incorporating the African Charter on Human and Peoples' Rights into domestic law as a source of law has been a controversial task. It was clear from the

\footnotetext{
*Corresponding author: William Edward Adjei. E-mail: weadjei@yahoo.com
}

Copyright (c) 2019 The Author(s). Published by VGWU Press

This is an Open Access article distributed under the terms of the Creative Commons Attribution License - Non Commercial - NoDerivs License (http://creativecommons.org/licenses/by-nc-nd/3.0/) which permits unrestricted $\underline{\text { use, distribution, and reproduction in any medium, provided the original author and source are credited. }}$ 
Adjei, W.E., (2019)

Re-assessment of "claw-back" clauses in the enforcement of human and peoples' rights in Africa

outset that, for its application and enforcement, the Charter [1] was not merely about human and peoples' rights, but represented a first step in the direction of the integration of Africa, as well as respect for national identities [2]. Despite the changing and gradually enhanced status of human and peoples' rights within Africa, the development of the general principles and fundamental rights enshrined in the Charter, has been subject to a number of criticisms [3]. A first concern is that civil and political rights in the Charter were left largely open, making the full enjoyment of individual rights, as well as group rights in Africa doubtful and ineffective; [4] and this will be elaborated below. A second concern is that the application of the "claw-back" clause [5] under the African Charter has paved the way for manipulation and misinterpretation as to what constitutes a legitimate valid law instead of protecting values which are genuinely fundamental to human condition [6]. All these concerns are to some extent related, and reflect a degree of scepticism in particular about the African Commission's ability to enforce a satisfactory system of human and peoples' rights protection for Africa. Some of the concerns raised are reflected in features such as "every individual shall have the right to express and disseminate his opinions "within the law" [7]. Similarly, in Article 8, freedom of conscience is "subject to law and order", and the right to liberty and security in Article 6 may be deprived "for reasons and conditions previously laid down by law" [8]. As mentioned earlier, such clauses of conditionality pursued by the Charter have meant that such provisions are subject to states' interpretation and manipulation. Article 10 (2) of the European Convention on Human Rights (ECHR) represents one of such instances, where the right to freedom of expression may be subject to such formalities, conditions, restrictions or penalties as are prescribed by the law and are necessary in a democratic society. This has produced intense academic discussion on the interpretation and implications of expression as an entrenched constitutional principle.

However, the difference with the African Charter is that the "claw-back" clauses were left rather broad and vague which stands in contrast to the ECHR [9]. With regard to other systems, universal as well as regional, [10] they include derogation clauses. Derogation clauses are different from "claw-back" clauses in that they explicitly provide circumstances in which rights may be limited and define rights that are non-derogable and must be respected, even when derogation is permitted [11]. Against the background of these concerns, Claude Welch has noted that "the African Charter itself permits the perpetration of violations of rights enshrined in it leading to human rights abuses". The essence of the critique was that the Charter gives rights, but permits them to be taken away, thus not protecting the individuals it is meant to protect.

Journal of Legal Studies Volume 24 Issue 38/2019

$S$ sciendo ISSN 2457-9017; Online ISSN 2392-7054.

Web: publicatii.uvvg.ro/index.php/jls. Pages $1-22$ 
Adjei, W.E., (2019)

As we have seen, the exercise of human and peoples' in Africa are violated every day by African dictators. This abusive development, which is most strikingly evident in Nigeria, Sudan, Zimbabwe and the Gambian cases, is problematic and complex. The Gambian Parliament, for example, had passed a National Media Commission Bill, which gave the Media Commission power to grant, suspend or withdraw registration of media practitioners; and also ousted the jurisdiction of any Court or Tribunal from entertaining any matter emanating from the Bill [12]. Also in the case of Wahab Akanmu v. Attorney-General of Lagos State [13], the court held that the African Charter cannot override domestic laws in Nigeria. Joshua Mzizi has affirmed Welch's above sentiments which reflected the powerlessness of enforcement agencies such as the African Commission and further observed that the African Charter itself is an obstacle to the more effective realisation of human and peoples' rights on the continent. He further argued that the Charter provides for a broad spectrum of rights and responsibilities, but it is woefully deficient in its enforcement machinery [14]. The point about the impact of "claw-back" clauses was expressed in a succinct fashion by Jean-Paul Masseron when he observed that "the leading statesmen of Africa have the tendency to sacrifice individual liberties in order to safeguard national independence" [15]. Considering the dangerous nature of these clauses, Bondzie-Simpson states that "these clauses seriously emasculate the effectiveness of the African Charter as well as its uniform application of member states" [16].

For our discussion, what is relevant is the fact that the African Charter places an emphasis on the provisions concerning civil and political rights that were felt central to any free and democratic society, and which required effective protection from the act of arbitrary governments in Africa. However, given the ambiguity and weakness of many of its provisions, this section will briefly provide an account of how "claw-back" clauses have impacted on the legitimate exercise of the human and peoples' rights either through governmental policies or by way of judicial interpretation of domestic rules. Relevant provisions will be analyzed to assess the compatibility of national laws with the African Charter on Human and Peoples' Rights. The point here is not to deprecate the need for state discretionary powers to limit measures to check human rights abuses in their locality, but also to highlight the deficiencies and inadequacies in the Charter's enforcement mechanism. It will also reveal how by allowing excessive use of "claw-back" clauses in the African Charter, those who wish to enjoy their human and peoples' rights are at a disadvantage to the exercise their rights and freedoms under the ACHPR. 
Adjei, W.E., (2019)

\section{The nature and the legal effects of claw-back clauses under the ACHPR:} enforcement difficulties

We have already noted that the substantive provisions of the African Charter are equivocally phrased which have given cause of concern [17]. The most problematic issues discussed in this section concern interpretation and enforcement. We have also seen in the Introduction that some governments in Africa excessively rely on "claw-back clauses" in the Charter as a tool for political repression and on individuals or group of people who tend to challenge governmental policies. What I propose to do in this section, is to demonstrate and measure the impact of vague laws, and the extensive use of "claw-back" clauses [18], that are discretionary in nature, unjustifiable and unrealistic. These clauses are often invoked to justify blatant suppression of free speech, gender discrimination and substantive rights under the Charter. Here, we shall be considering relevant provisions relating to "claw-back" clauses to ascertain the impact of these clauses that aggravate the enjoyment of some of the rights enshrined in the African Charter. We will use the terms "enforcement" and "implementation" interchangeably, although not everyone would agree that they have the same precise meaning.

We shall also see in this section that the term "claw-back" clauses is not straightforward. As we saw in Chapter 1, they have the capacity to limit the reach of human and peoples' rights, mentioned earlier [19]. In recognising the impact of "claw-back" clauses, Vincent Orlu Obisienuwo Nmehielle looked at the conflict between national laws and international human rights instruments in their discriminatory context. This is what he said:

Those provisions of the African Charter that tend to limit some of the rights guaranteed under the Charter, they do not as outright derogate clauses that are found in other international human rights instruments. They rather qualify the enjoyment of the right as contingent upon other notions of state prescription [20].

It is obvious that these provisions raise a number of complex and potentially litigation issues. The reality, however, is that many of these "claw-back" clauses subject the provisions of the Charter to national laws and to the discretion of state authorities in that they qualify the observance of the principles in the Charter under certain circumstances [21]. There is discussion of these and other aspects of interpretation and legal effect below. In the analysis of relevant provisions affected, the African Commission relied on the test as laid down, for example, in Amnesty International and Others $v$. Sudan. In order to constitute a reasonable limit on a constitutional right the government had to demonstrate that the legislation addressed a pressing and substantial objective and that it did so by the least invasive means. The courts will be required to interpret domestic laws in a way which is compatible with these Charter rights. As is well known, these rights are: the right to liberty and security; the right to a fair trial; the freedom of thought,

4 Journal of Legal Studies Volume 24 Issue 38/2019

$S$ sciendo ISSN 2457-9017; Online ISSN 2392-7054.

Web: publicatii.uvvg.ro/index.php/jls. Pages $1-22$ 
Adjei, W.E., (2019)

Re-assessment of "claw-back" clauses in the enforcement of human and peoples' rights in Africa

conscience, religion, expression, assembly and association; and the right to effective participation in public affairs. It is obvious that many of the substantive provisions in the ACHPR are riven with qualifications without reasonable justification; and this will be addressed below.

\section{The Right to Liberty and Security of the Person and Freedom from Arbitrary Arrest (Art. 6)}

Article 6 of the ACHPR stipulated that "every individual shall have the rights to liberty and to the security of his person. No one may be arbitrarily deprived of this freedom "except for reasons and conditions previously have been laid down by law." The most problematic aspect of Article 6 is the condition that the African Charter has not provided the necessary protection for the individual in the society. Although this provision recognizes in the first sentence, the right to liberty and security, and then proceeds to remove the certainty of the right in the second sentence. Therefore, the individual is given the right and simultaneously deprived of it because it is subject to domestic constraints that often deprive the populace of all legal protection [22]. In Amnesty International and Others v. Sudan, the African Commission was confronted with the broad interpretation of national law and what constitutes a "law". Pronouncing in the arbitrary execution of twenty-eight army officers; the Commission states: "It is not sufficient for the government to state that these executions were carried out in conformity with its legislation. As we have seen, the African Commission requires the government to provide justifiable evidence that its laws are in accordance with the provisions of the African Charter, and that in the conduct of the trials the accused's right to defence was scrupulously respected" [23]. A fundamental principle of legality states that the" law" must be sufficiently clear to offer predictability, accessibility and foreseeability and to guard against arbitrariness. Making a "law" clear and accessible requires not only strict conformity with national law, but also with the principles of the other regional and international norms. The Commission has rejected a series of attempts to use "claw-back" clauses to suppress political expression. The outstanding example is Grayned v. City of Rockford, where the U.S. Supreme Court interpreted the precise meaning and the importance of rule of law, as including predictability and accessibility, held that "laws should give the person of ordinary intelligence a reasonable opportunity to know what is prohibited, so that he may act accordingly" [24].

\section{The Right to a Fair Trial (Art. 7)}

Article 7 of the ACHPR provides for some protection for the individual in the form of procedural safeguards to enable him to have his cause heard, the right of appeal to a competent national organ, the right of appeal or to an effective remedy, the 
Adjei, W.E., (2019)

Re-assessment of "claw-back" clauses in the enforcement of human and peoples' rights in Africa

presumption of innocence, the right to defence counsel of one's choice and a trial within a reasonable time by an impartial court or tribunal. This is, however, limited to domestic laws being carried out by "competent national organs" or a "competent court or tribunal" [25]. No one may be tried for an act or omission which was, at the time it was committed, not an offence or for an offence for which no provision was made. Provision of Article 7 is silent on what a "fair" civil trial requires. There is also no requirement that the trial should be in public. Nigeria under military regimes passed a large number of laws that did not comply with the standards of fair hearing [26]. The best known of these decrees include the state security (detention of persons) Decree No. 2, recovery of public property (special military tribunal) Decree No. 3, the public officers (protection of false accusation) Decree No. 4 and special tribunal (miscellaneous offences) Decree No. 20, all of 1984. In any case, various African governments, like Nigeria are known for the use of retroactive legislation to achieve their dictatorial tendencies, and will thus find the "claw-back" clauses a veritable source of inspiration. The Nigerian case below demonstrates the African Commission's readiness to articulate a strong interpretation obligation and to provide firm guidance to the national court in this respect.

Thus, in considering the scope and the meaning of the right to a fair trial in civil matters, the African Commission on Human and Peoples' Rights in Civil Liberties Organisation, Legal Defence Centre, Legal Defence and Assistance Project v. Nigeria [27] has held that:

The provisions of Article 7 should be considered non-derogable providing as they do the minimum protection to citizens and military officers alike especially under an unaccountable and undemocratic military regime.

\section{Freedom of Conscience and Religion (Art. 8)}

Religious freedom provides another striking illustration of where "claw-back" clauses have impacted on individual's freedom. Thus, although this right is guaranteed under Article 8 of the African Charter, it goes further to qualify the right by providing that "no one may, subject to law and order, be subjected to measures restricting the exercise those freedoms." Despite of the fact that the right to religious freedom is a very important right which ought not to be vaguely defined, in Nigeria; twelve states have recently adopted the Islamic legal system which curtails the rights of non-Muslims in those states to practice and observe their religion. Thus, although the African Commission has frequently emphasized that any limitation to this right must be "prescribed by law" or "within the law", under the Shari'a law, ridda (change of religion) is a capital offence. This means that where the offence of ridda is provided by law, then a person prosecuted for violating the offence cannot have recourse to the African Charter on Human and

$\begin{array}{ll}\text { S Sciendo } & \begin{array}{l}\text { Journal of Legal Studies Volume 24 Issue 38/2019 } \\ \text { ISSN 2457-9017; Online ISSN 2392-7054. } \\ \text { Web: publicatii.uvvg.ro/index.php/jls. Pages 1 } 1 \text { - } 22\end{array}\end{array}$


Adjei, W.E., (2019)

Re-assessment of "claw-back" clauses in the enforcement of human and peoples' rights in Africa

Peoples' Rights. Amnesty International v. Sudan [28] judgement provides further evidence of the continued significance of one's freedom to manifest his religion and beliefs. This is an outstanding example where the African Commission has recognized the centrality of religious freedom, maintaining that the state party violated the author's right to practice and observe religion because non-Muslims did not have the right to preach or build their churches and were subjected to harassment, arbitrary arrest, and expulsion. In defining the meaning of a citizen's religious freedom under Article 8 of the ACHPR, the Commission refused to apply any conflicting rules of national law, even in cases concerning Christians and Muslims.

\section{Freedom of Expression and the Right to Disseminate one's Opinion (Art. 9)}

Article 9 (2) of the ACHPR provides an example of what is termed a "claw-back" clause: "Every individual shall have the right to express and disseminate his opinions within the law." From the quotation it can be observed that the freedom of expression generally entitles an individual to communicate different types of information without fear of intervention by the national authorities. However, an individual does not have the right per se to receive information. The expression "within the law" constitutes a so-called "claw-back" clause [29], a limitation that is built into the freedom of expression provisions. This provision recognises, in the first instance, the right to freedom of expression, and then proceeds to remove the certainty of the right in the second instance, leaving the African Commission without a meaningful supervisory role and the victim of a violation without recourse [30]. Therefore, the individual is given the right and simultaneously deprived of it because it is subject to domestic constraints that often deprive the populace of all legal protection. In this respect, the protection guaranteed by Article 9 (2) of the ACHPR may be considered useless [31], since such right would be entirely subjected to the ramifications of national law. The effect of the phrase "within the law" has long been taken to be that no domestic legal provision which limits the right in question may be challenged in terms of the Charter. The word "law" was understood to mean "domestic law". This is indeed the obvious meaning of such a provision, and it has rightly been the subject of stringent criticism of the Charter, since that would imply that international supervision of domestic law is ruled out in respect of these rights, defying the very reason for the existence of a regional human rights system [32]. For example, under the military regime of Burhari and Idiagbon enacted Decree No. 4 of 1984. Although it was for the protection against false accusation, it protected public officials from media scrutiny. The effect of this Decree was succinctly stated by Adefarasin, CJ in Guardian Newspaper v. Attorney-General of the Federation [33]: 
Adjei, W.E., (2019)

By the foregoing provision it is unlawful for a person to publish a report or statement which brings or is calculated to bring the Federal Military Government or a public officer to ridicule or disrepute even if the publication is true.

This Decree constitutes an infringement of the right to freedom of expression. Being part of the laws of the country, it can legitimately limit the right to freedom of expression and media freedom enshrined in the African Charter on Human and Peoples' Rights [34]. By focusing on the duty of the national courts and their duty to deal with conflicting national law, the African Commission in Civil Liberties Organisation in respect of the Nigeria Bar Association v. Nigeria ruled that the term "law" in these clauses should in fact be understood as a reference to international law [35]. The African Commission's decision in this controversial area as to what constitutes a legitimate law, and the regulation of free speech, demonstrate the potential for an effective political democracy and free expression in Africa.

\section{The Right to Freedom of Association (Art. 10)}

Under Article 10 (1) of the African Charter provides that an individual has the right to freedom of association "provided that he abides by the law." This provision, is a particularly strongly worded qualification and fear has been expressed that the term "law" in this provision would be interpreted to justify and excuse any action whatsoever taken by governments, as long as such action is couched in legislation or otherwise conforms with "law" [36]. This clause, as has been noted, vest wide discretionary powers in the enforcement bodies, allowing them to ban or restrict public rallies and demonstrations, as well as what can be said at such gatherings.

An important aspect of individual's freedom of association is the right to form and join political party and trade unions for the protection of his/her interests. Yet, while the international bills of right and other two regional instruments specifically mentioned the right to form or belong to a political party or trade union, Article 10 of the ACHPR is silent on what "freedom" of association requires, for example, the right to strike and engage in collective bargaining. This vague approach to law gives existing governments room to stifle opposition political parties on a number of grounds, including national security, the prevention of disorder of crime, and the protection of the rights and freedoms of others (Article 27 (2) of the ACHPR). These restrictions are permitted by preventing the group holding political rallies, and jailing opposition leaders for holding "illegal" assemblies or uttering "seditious" statements as such gatherings which is common in Africa.

However, this fear of misuse of the "law" has been addressed by the African Commission on Human and Peoples' Rights by adopting a strict approach to its interpretation of Article 10 of the ACHPR. The leading case on the right to association is Communication 101/93. The African Commission decided that: 
Adjei, W.E., (2019)

Re-assessment of "claw-back" clauses in the enforcement of human and peoples' rights in Africa

Competent authorities should not enact provisions which limit the exercise of this freedom. The competent authorities should not override constitutional provisions or undermine fundamental rights guaranteed by the constitution and international human rights standards. The limit should be consistent with states' obligations under the African Charter [37].

The Right to Participate Effectively in Public Affairs (Art. 13)

Article 13 (1)'s guarantee of "every citizen the right to participate in the government of his country, either directly or through freely chosen representatives," has been shrunk in a similar way. This is because the same provision is subject to a "claw-back" clause, "in accordance with the provisions of the law" which has the potential for silencing political dissent and one's right to effectively participate in public affairs. The implication of this provision is that if the national law provides, for example, for a One-Party State or criminal sanction for reporting falsehood, as is usually the case in Africa, the right to participate effectively in public affairs is not violated. This is a major concern raised by opposition parties and journalists in Africa. Clearly, the application and reliance of "claw-back" clause permits a wide margin of discretion to African governments and political leaders to order their political system as they deem fit, which as pointed out includes suppression of political dissent [38] and the institutions of a One-Party State [39]. This issue of manipulation and misinterpretation of the "law" has also been of major concern raised by marginalized ethnic groups in Africa [40]. (Cf. also Malawi African Association and Others v. Mauritania; Katangese Peoples' Congress v. Zaire and International PEN, Constitutional Rights Project, Interights on behalf of Ken Saro-Wiwa Jr. and Civil Liberties Organisation v. Nigeria). In all these cases, the Commission has maintained that the rights to participate effectively in public affairs are guaranteed "subject only to such reasonable limits prescribed by law as can be demonstrably justified in a free and democratic society".

Indeed, effective participation is a key aspect of the contemporary governmental politics of recognition pursued by many groups, suggesting the importance of group-differentiated rights as a characteristics route to fulfilling their aspirations. Yet, under the African Charter, the right to political participation is given scanty protection when measured against international standards [41]. There are numerous examples of cases where the African Commission has struck down national rules that are found to be vague, discriminatory, discretionary, and lacks clarity. This means that the issue of what constitutes the term "law" will have to be addressed, and the Commission has done so on a number of occasions. 
Adjei, W.E., (2019)

3. The case-law of the African commission: exploring the limits of national authorities

In the previous chapter, we analysed the nature and the legal effects of "claw-back" clauses under the African Charter. We now consider a number of other general principles that have featured prominently within the African Commission's jurisprudence: proportionality, legality, compatibility, appropriate balancing, equality and non-discrimination, and the more recently developed principles of necessity and transparency. We will further address some of the implications of section 2, dealing first with the African Commission's strict interpretation of the term "law" by various public authorities which adversely affect the enjoyment of the rights and freedoms guaranteed under the African Charter; secondly with the effect of embracing the Commission's judgments within the Charter; and thirdly with the consequences of extending the decisions and opinions of the African Commission to national courts. The vague and open-ended nature of "claw-back" clauses has meant that over the years their meaning has in large part come to depend as much on the judgments of the African Commission. Indeed, the case-law of the Commission discussed below exemplified the difficulties inherent in the "claw-back" clauses.

A brief look at the Commission role is therefore timely, especially since it addresses matters that are central to the debate about "claw-back" clauses and individual rights and freedoms in the African Charter. Thus, although the Commission was set up under the African Charter to ensure the protection of human and peoples' rights throughout the African continent [42], it has been criticised for being relatively toothless [43]. In the area of protection, the Commission gathers information, establishes facts, concludes and makes recommendations to the heads of state and considers individual complaints of violations of the African Charter [44]. However, whether the Commission will be perceived as an effective institution for the protection of human rights in Africa will largely depend on how far and how much the state parties to the African Charter take seriously, and respect the Commission's views and recommendations. This section will along with relevant case-law of the African Commission, investigate the application and the use of "claw-back" clauses in order to determine whether these aspects of national laws introduced are incompatible with the African Charter which is the regional instrument for the realisation of human and peoples' rights. We will also assess the effectiveness and validity, whether such laws strike an appropriate balance between the achievement of their objectives and the protection of human and peoples' rights under the ACHPR.

Evaluating the consequences of illegality and invalidity in applying national rules, the African Commission has in several occasions applied civil and political rights to a wide range of situations including stifling opposition political parties views,

10 Journal of Legal Studies Volume 24 Issue 38/2019

$S$ sciendo ISSN 2457-9017; Online ISSN 2392-7054.

Web: publicatii.uvvg.ro/index.php/jls. Pages $1-22$ 
Adjei, W.E., (2019)

Re-assessment of "claw-back" clauses in the enforcement of human and peoples' rights in Africa

mass expulsions of non-nationals, arbitrary detentions of journalists, bans of political activities, sham trials and discrimination on many grounds including race and national origin. Such developments of abuses and lack of legal protection of rights and freedoms in Africa were vividly highlighted in Institute for Human Rights and Development in Africa v. Republic of Angola [45], in which the African Commission strongly emphasized the importance of rule of law and human rights protection. The case involved a mass deportation of hundreds of Gambian workers by Angola in 2004 without any legal protection. In this case, the African Commission was concerned about the illegitimate and illegal domestic laws governing due process and their consistency with the provisions of the African Charter. Although the Commission considered that African states may expel nonnationals from their territories, it also remarked that the measure that they take in such circumstances should not be taken to the detriment of the enjoyment of human rights. The Commission, in addressing the impact of "claw-back" clauses, maintained that while the African Charter does not bar a state's right to deport nonnationals per se, it does require deportations "within the law" and to take place in a manner consistent with the due process of law [46].

Due to the abusive nature of these "claw-back" clauses [47], some African governments have enacted laws that empower different state functionaries to issue a detention order against any person engaged in acts prejudicial to national security. The African Commission followed a similar pattern of reasoning in Civil Liberties Organisation (in respect of the Nigerian Bar Association) v. Nigeria [48]. Recognizing the importance of the right to form associations and to belong to trade unions, the African Commission reiterated that:

In regulating the use of this right, the competent authorities should not enact provisions which should limit the exercise of this freedom. The competent authorities should not override constitutional provisions or undermine fundamental rights guaranteed by the constitution and international human rights standards.

Similar rulings were given in such cases as: Media Rights Agenda, Constitutional Rights Project, Media Rights Agenda, Constitutional Rights Project v. Nigeria [49], examining the legal effects of "claw-back" clauses introduced in national laws which has the potential for political manipulation. The African Commission, in this case, adopted a restrictive interpretation to judicial decisions which must be consistent with international law [50]. The Commission noted that in relying on "claw-back" clauses on local and national levels, the courts cannot provide checks on the executive branch of the government because they subject provisions of the African Charter to national laws which are often inconsistent with their obligation to international law [51]. The Commission insisted that:

To allow national law to have precedent over the international law of the Charter would defeat the purpose of the rights and freedoms enshrined in the Charter. 
Adjei, W.E., (2019)

International human rights standards must always prevail over contradictory national law. Any limitation on the rights of the Charter must be in conformity with the provisions of the Charter [52].

A broader interpretation of the phrase "within the law" or "in accordance with the law" was clearly evident in Scanlen \& Holderness v. Zimbabwe [53]. In this case, the African Commission found that the Zimbabwean Access to Information and Protection of Privacy Act 2002 (AIPPA) was repressive and illegal; an imposition of excessive burden on journalists; and a restriction on their legitimate enjoyment of the right to freedom of expression and media information. Even though the Zimbabwe government argued that the "law" referred to in Article 9 of the ACHPR relate to "domestic law" [54], the Commission found that Section 80 of the Act 2002 was not "law" because it was vague and its interpretation and application contravenes Article 9 of the ACHPR. It has already been seen that for expression to be "within the law," the domestic legislation must be compatible with the African Charter or other international human rights instruments and practice in order not to render the African Charter ineffective and meaningless [55]. The Commission also upheld the phrase "within the law" as required a consideration of "whether the restrictions meet the legitimate interests, and are necessary in a democratic society" [56] and that the phrase "within the law" as employed in the Charter cannot be divorced from the general concept of the protection of human rights and freedoms [57].

The African Commission has also been concerned where states have invoked the African Charter's limitations clause to justify deporting citizens based on vague public order grounds. Two Zambian cases clearly illustrate this concern: Legal Resources Foundation v. Zambia [58] and Amnesty International (on behalf of Banda and Chiniwa) v. Zambia [59]. In Banda case, the respondent State relied on "claw-back" clause of Article 12 (2) of the ACHPR to defend its deportation of victims. Treating them as "claw-back" clauses, the Commission has not paid much heed to the norm-based nature of these restrictions. In this case, for example, the Zambian government in 1994 deported two leading politicians after serving them with deportation orders, stating that their continued presence in Zambia would likely "be a danger to peace and good order to Zambia." The complainants alleged, amongst other things, that their right to "leave any country... and to return to his country" had been infringed [60]. The government invoked the limitation clause contained in the same provision, to the effect that: this right may only be subject to restrictions, "provided for by law for the protection of national security, law and order, public health and morality." Rejecting the contention that the mere fact of a deportation or is sufficient to meet these standards, the Commission observed as follows: 
Adjei, W.E., (2019)

The Commission is of the view that the "claw-back" clauses must not be interpreted against the Charter. Recourse to them should not be used as a means of giving credence to violations of the express provisions of the Charter [61].

In the case concerning ARTICLE $19 v$. Eritrea [62], an international human rights organisation based in United Kingdom (ARTICLE 19), submitted a communication against the State of Eritrea, on behalf of eighteen (18) journalists. The complainants alleged that in August 2001, several senior officials and other members of the ruling elite, known as the G15, signed a public letter criticising President Isaias Afewerki's rule. The alleged letter generated a political crisis that resulted in dismissal of top officials, imprisonment of government critics and journalists, and the cancellation of elections planned for December 2001. Thereafter, the government imposed a ban on the entire private press, and arrested and detained 18 journalists incommunicado without trial. Eritrea's argument, then, is that its actions were justified by the circumstances prevailing within its territory during the relevant period and permissible under its domestic law [63]. Reference is made to Articles $6 \& 9$ of the African Charter, the relevant sections of which provide respectively that:

No-one may be deprived of his freedom except for reasons and conditions "previously laid down by law," and every individual shall have the right to express and disseminate his opinion "within the law."

One of the inherent problems in such clauses is one of consistency. In one part of the provision, individual shall have the right to express himself freely, whereas in another area the individual has to exercise this right "within the law". Such inconsistencies as noted earlier, lead to uncertainty in the law and confidence by the public in the legal system being eroded. If "law" is interpreted to mean any domestic law regardless of its chilling effect, State Parties to the African Charter would be able to negate the rights conferred upon individuals as well as groups by the Charter [64].

In a number of other cases the African Commission upheld "claw-back" clauses as constituting a reference to international law, meaning that only restrictions on rights which are consistent with the Charter and with states parties' international obligations should be enacted by the relevant national authorities [65]. The Eritrean case provides a good illustration of the problems posed by "claw-back" clauses. It was argued that the lawfulness of Eritrea's action must therefore be examined against the Charter and other norms of international law, rather than by reference to its own domestic law alone [66]. In fact, in all the cases cited above, the Commission found that the "claw-back" clauses render international supervision of domestic law and practice meaningless, non-existent, ineffective or illusory. They create a legal situation which constitutes a form of a permit for the already unwilling State to engage in wanton and routine breach of the Charter obligations 
Adjei, W.E., (2019)

using the reasons of public utility or national security [67]. It is now accepted that all rights in the African Charter on Human and Peoples' Rights may justifiably be limited in terms of Article 27 (2) of the ACHPR, which reads as follows: "the rights and freedoms of individual shall be exercised with due regard to the rights of others, collective security, morality and common interest" [68].

Once the complainants have established that there is a prima facie violation of a right [69], the respondent state may argue that the right has been legitimately encroached upon by "law", by providing evidence that the encroachment serves on of the purposes set out in Article 27 (2) [70]. The African Commission has consistently maintained that the "only legitimate reasons for interfering with individual rights and freedoms of the African Charter" are found in Article 27 (2) of the ACHPR [71]. According to the Commission, the interference must take the form of "law" which does not "apply specifically to one individual or legal personality," as illustrated in the Nigerian Newspaper Proscription case. The Nigerian military government in 1994 issued three decrees proscribing The Concord, the Guardian, and Punch newspapers, each by name [72]. The Complainants argued that these decrees violated Article 9 (2) of the Charter, amongst other provisions. As regards to this provision, every individual has the right to freedom of expression "within the law." The government argued that the decrees constituted "law," as that term refers to the current Nigerian law and not to constitutional or international standards, and argued that the decrees were justified by special circumstances. In assigning a meaning to freedom of expression, for example, the Commission has said that the decrees constituted "law", but held that national laws or rules which targeted "one individual or legal personality raise the serious danger of discrimination" [73]. More broadly still, the Commission has declared its preference for a strong principle of interpretation and for reading the Charter "purposefully", to give effect to its overarching values such as human dignity, personal autonomy, pluralism and non-discrimination. This approach is encouraging because it means that African Charter is not neutral on practices, which promote inequality and political manipulation of laws. Rather, it has a constitutional commitment to ending them.

\section{Conclusions}

\section{The implications of entrenching the Charter Rights}

The aim of this essay has been to highlight the importance human rights protection in Africa as follows. First, I have tried to sketch and elucidate some of the intellectual assumptions on which the African Charter on Human and Peoples' Rights rested, and identified a conception of "law" which seems to have emerged alongside that idea of national rules. Secondly, I have argued that recent African Commission's broad and strict interpretation of the Charter provisions relating to

14 Journal of Legal Studies Volume 24 Issue 38/2019 
Adjei, W.E., (2019)

"claw-back clauses have resulted in changes both in scope and significance of the African Charter and in the judiciary' conception of the idea of law. Thirdly, and more specifically, I have tried to indicate that the application of "claw-back" clauses by some African States and public authorities negatively impacts on human and peoples' rights in Africa. These clauses, as has already been indicated, are used by political leaders to restrict the reach of the rights and freedoms that the African Charter guaranteed. They give African political leaders power to create and change laws regardless of their effects. In Nigeria under past military regimes, for example, laws are formulated by making the fundamental human rights provisions of the Constitution impotent, while the Court's jurisdiction was ousted generally [74]. And fourthly, I have noted that drawing from international and regional legislative instruments has not always yielded laws that enhance human rights protection in Africa.

However, the African Commission in its jurisprudential approach and its desire to promote and protect human rights in Africa has contained the impact of the use of those "claw-back" clauses by interpreting the provisions in relation to international human rights standards based on principles of 'rationality' and 'proportionality'. Thus, the Commission's role in this respect is significant and it has demonstrated its willingness to challenge the "illegality" and the "illegitimacy" of the limitations imposed by national laws that are inimical to political freedom and democratic governance. My general objective has been to show that a broad interpretation of the term "law" is of basic constitutional importance. These jurisprudential developments must be viewed as an essentially political project by the judiciary in response to the issues raised in this essay. Accordingly, I wish to end this essay with these remarks from Sir Shridath Ramphal [75] relating to the importance of law in a free and democratic society:

The rule of law has been a critical civilising influence in every free society. It distinguishes a democracy from a tyrannical society; it secures liberty and and justice against repression; it elevates equality above dominion; it empowers the weak against the unjust claims of the strong. Its restrains, no less than the moral precepts it asserts, are essential to the well-being of a society, both collectively and to individuals within it. Respect for the rule of law is thus a basic neighbourhood value. And one that is certainly needed in the emerging global neighbourhood.

\section{Acknowledgements}

The author thanks the anonymous reviewers and editor for their valuable contribution.

\section{Funding}

This research received no specific grant from any funding agency in the public, commercial, or not - for - profit sectors. 
Adjei, W.E., (2019)

"Vasile Goldiş" Western University of Arad

Re-assessment of "claw-back" clauses in the enforcement of human and peoples' rights in Africa

\section{Author Contributions}

The entire article was written by William Edward Adjei.

\section{Disclosure Statement}

The authors have not any competing financial, professional, or personal interests from other parties.

\section{Notes}

[1] African (Banjul) Charter on Human and Peoples' Rights (the "Charter"), adopted 27 June 1981, OAU Doc. CAB/LEG/67/3 rev. 5, 21 ILM 58 (1982), entered into force 21 October 1986; See also Umozurike U. O. "The African Charter on Human and Peoples' Rights" (1983) American Journal of International Law, pp. 902-912; Gino J. Naldi (ed.) Documents of the Organisation of African Unity (1992) 109; Gino J. Naldi, "Limitation of Rights Under the African Charter on Human and Peoples' Rights: The Contribution of the African Commission on Human and Peoples' Rights," (2001) South African Journal on Human Rights, Vol. 17, No. 1; Amos O. Enabulele, "Incompatibility of National Law with the African Charter on Human and Peoples' Rights: Does the African Court on Human and Peoples' Rights have a final Say? (2016) African Human Rights Law Journal, Vol. 16, No. 1.

[2] For a comprehensive overview of the system, see M Evans and R Murray (eds), The African Charter on Human and Peoples' Rights: The System in Practice $\left(2^{\text {nd }}\right.$ edn OUP, Oxford 2008); F Viljoen, International Human Rights Law in Africa (OUP, Oxford 2007) Chs. 7-12. The African Charter on Human and Peoples' Rights, available at: http://www.achpr.org/instruments/achpr/ ; Ebow Bondzie-Simpson, 'A Critique of the African Charter on Human and People's Rights' [1988] 31 Howard Law Journal 643, 660; Christof Heyns, 'The African Regional Human Rights: The African Charter' [2003-2004] 108 Penn St. L. Rev. 679, 695.

[3] Hansungule, M., "The African Charter on Human and Peoples' Rights: A Critical Review" (2004) 8 African Yearbook of International Law 265-331. See also Mutombo Nkulu N'Sengha, "The African Charter on Human and Peoples' Rights: An African Contribution to the Project of Global Ethics" (December 2010).

[4] See for example, Thompson SS (2008); Mukundi G., "A Critical Examination of the African Charter on Human and Peoples' Rights: Towards Strengthening the African System for the Promotion of Human and Peoples' Rights to Enable it to Effectively Meet the Needs of the African Population," in F. Viljoen (ed.) The African Human Rights System: Towards the Co-existence of the African Commission on Human and Peoples' Rights and the African Court and Peoples' Rights (2006), pp. 1-30; Loveness Mapuva, "Negating the Promotion of Human Rights Through "Claw-Back" Clauses in the African Charter on Human and Peoples' Rights," (2016) International Affairs and Global Strategy, Vol. 51; BBC-World Service (2008), Human Rights Agreements in Africa, Europe and the Americas, and Regional Courts. Available at: 
Adjei, W.E., (2019)

Re-assessment of "claw-back" clauses in the enforcement of human and peoples' rights in Africa

http://www.bbc.co.uk/worldservice/people/features/ihavearightto/four_b/treaties_regional.s html.

[5] In its conventional sense, the "claw-back" concept relates to abandonment or a deliberate breach of an obligation for a given reasons.

[6] Higgins R. "Derogation under Human Rights Treaties," (1978) 48 British Yearbook of International Law, 281, p. 281.

[7] Article 9 (2) of the African Charter

[8] Ouguergouz F., The African Charter on Human and Peoples' Rights: A Comprehensive Agenda for Human Dignity and Sustainable Democracy in Africa, The Hague/London/New York: Martinus Nijhoff Publishers, 2003, p.61. See for instance, Articles 9, 10, 12, 13 (1) in the African Charter.

[9] See Timothy Fwa Yerima, "Comparative Evaluation of the Challenges of African Regional Human Rights Courts" Vol., No. 2, Journal of Politics and Law, September 2011; Lucinda Patrick-Patel, The African Charter on Human and Peoples' Rights: How Effective is this Legal Instrument in Shaping a Continental Human Rights Culture in Africa? 2018.

[10] Article 29 (2) of the UNDR, 4 of the ICCPR, Article 15 of the ECHR, Articles 29 and 30 of the AmCHR.

[11] Gittleman, R., "The Banjul Charter on Human and Peoples' Rights: A Legal Analysis" in C. E. Welch \& R. I. Meltzer, Human Rights and Development in Africa (1984), pp 56165; Gittleman, “R., The African Commission on Human and Peoples' Rights: Prospects and Procedures", in Hurst Hannum (ed.), Guide to International Human Rights Practice (Philadelphia: University of Pennsylvania Press, 1984; Rosalyn Higgins, "Derogations under Human Rights Treaties" (1978) 48 British Yearbook of International Law; For further reading, see Jean Allan, "Derogation from the European Convention on Human Rights in the Light of other Obligations under International Law" (2005) 5 European Human Rights Law Review 480; De Zayas, in Premont, Stenersen and Oseredczuk, ed. Non-Derogable Rights and States Emergency (1996), p. 225.

[12] Udombana, N. J. “Toward the African Court on Human and Peoples' Rights: Better Late than Never" (2003) 3 Yale Human Rights and Development Law Journal 45-111.

[13] Wahab Akanmu v. Attorney-General of Lagos Suit M/568/91.

[14] See for example, Joshua Bhekinkosi Mzizi, "Human Rights, Peace and the African Charter on Human and Peoples' Rights" (1998) African Legal Aid Quarterly 37; P. K. A. Amoah, "The African Charter on Human and Peoples' Rights: Implementation Machinery" Gaborone Seminar; Fekadeselassie F. Kidanemariam, "Enforcement of Human Rights under Regional Mechanisms: A Comparative Analysis" (2006) LLM Theses and Essays, 80, also available at: https://digitalcommons.law.uga.edu/stu_llm/80.

[15] See K. M'Baye and B. Ndiaye, "The Organisation of African Unity", in K. Vasak (ed.), The International Dimensions of Human Rights, revised and edited for English edition by Philip Alston, Vol. 2, Westport, Conn: Greenwood Press, 1982, p. 594.

[16] E. Bondzie-Simpson, "A Critique of the African Charter", (1988) 31 Howard Law Journal 643-665.

[17] See D'Sa, "The African Charter on Human and Peoples Rights: Problems and Prospects for Regional Action," (1981/83) 10 Australian Yearbook of International Law 101. 
Adjei, W.E., (2019)

Re-assessment of "claw-back" clauses in the enforcement of human and peoples' rights in Africa

[18] See Sandhiya Singh, "The Impact of "Claw-Back" Clauses on Human and Peoples' Rights in Africa," African Security Review 18 (4) Institute for Security Studies, 100-102; Priti Patel, "For Women in Botswana, Victory Against a "Claw back Clause" (September 27, 2013): Although the Constitution prohibits gender discrimination, it exempts all laws addressing "adoption, marriage, divorce, burial, devolution of property on death or other matters of personal law" from this prohibition. This kind of exemption is often referred to as a "claw-back clause" and can be found in a number of constitutions throughout southern Africa, including in Lesotho and Swaziland. It is often invoked to justify blatant gender discrimination.

[19] See for example, R. Higgins, "Derogation under Human Rights Treaties," (1976-1977) 48 The British Yearbook of International Law, 28; Dinjens E \& Fleurke F (2002:6); F. R. M. Dlamini, "Towards a Regional Protection of Human Rights in Africa: The African Charter on Human and Peoples' Rights (1991) 24 Comparative and International Law Journal of South Africa 189-203 at 196; R. M. D'Sa, “The African Charter on Human and Peoples' Rights: Problems and Prospects for Regional Actions" [1987] Australian Yearbook of International Law 101-103 at 109.

[20] Vincent Obisienuwo Orlu Nmehielle, "The African Human Rights System: Its Laws, Practice, and Institutions," Martinus Nijhoff Publishers, The Hague/London/New York, 2001, p. 165

[21] C. M. Shaw, "The Evolution of Regional Human Rights Mechanisms: A Focus on Africa," Journal of Human Rights, 6 (2007), pp. 209-232, at 214.

[22] See for example, Rose D'Sa, "Human and Peoples' Rights: Distinctive Features of the African Charter" (1985) 29 (1) Journal of African Law, 72-81; Rose D’Sa, "The African Charter on Human and Peoples' Rights: Problems and Prospects for Regional Action," (1987) Australian Yearbook of International Law 101-130; and Rose D'Sa, "The Domestic Application of the African Charter on Human and Peoples Rights," (1989) 2 Developing Human Rights Jurisprudence 101-124.

[23] Case 48/90, 50/91, 89/93, Amnesty International, Comite Loosli Bachelard, Lawyers Committee for Human Rights, Association of Members of the Episcopal Conference of East Africa v. Sudan (Amnesty International and Others v. Sudan), decision of 11 May 2000, para. 66.

[24] Grayned v. City of Rockford,: 408 U.S. 104, 92 S Ct 2294 (1972), 2299.

[25] Article 7 (1) (b) and (d) of the ACHPR.

[26] See M. A. Owoade, "Human Rights and the Criminal Justice System in Nigeria from Buhari to Babangida", (1988) 9 Human Rights Law Journal, paras 2-3, 181-203; O. Agbede, "Law and Social Justice: The Nigerian Experience," Annual Lecture of PostGraduate School, Obfemi Awolowo University, Ile-Ife, Nigeria, 2 June 1987; Smith, I. O., "Enforcement of Human Rights Treaties in a Military Regime: Effect of Ouster Clauses on the Application of the African Charter on Human and Peoples' Rights in Nigeria" (2000) 9 (2) Review of the African Commission on Human and Peoples' Rights, pp. 192-205.

[27] Civil Liberties Organisation, Legal Defence Centre, Legal Defence and Assistance Project v. Nigeria: African Commission on Human and Peoples' Rights, Communication No. 218/98.

[28] Amnesty International v. Sudan (2000) AHRLR 297 (ACHPR 1999).

18 Journal of Legal Studies Volume 24 Issue 38/2019

$S$ sciendo ISSN 2457-9017; Online ISSN 2392-7054.

Web: publicatii.uvvg.ro/index.php/jls. Pages $1-22$ 
Adjei, W.E., (2019)

Re-assessment of "claw-back" clauses in the enforcement of human and peoples' rights in Africa

[29] Claw-back clauses are described as internal modifiers qualifying rights and permit a state to restrict "to the maximum extent permitted by domestic law" (For this definition, see M. Mutua, "The African Human Rights System: A Critical Evaluation", 6; also available at: <http://www.hdr.undp.org/docs/pubications/background_papers/MUTUA.pdf (accessed 12 July 2011).

[30] For further discussion on Article 9 (2) of the ACHPR and "claw-back" clause, see Christof Heyns and Magnus Killander, "Africa in International Human Rights Textbooks" (2007) 15 (1) African Journal of International and Comparative Law, 130-137.

[31] For further reading, see Evelyn A. Ankumah, "The African Commission on Human and Peoples' Rights, Practice and Procedures (The Hague/London/Boston: Martinus Nijhoff Publishers, 1996), pp. 135-136; Lindholt Lone, "Questioning the Universality of Human Rights: The African Charter on Human and Peoples' Rights in Botswana, Malawi and Mozambique, 1997, pp. 156-161.

[32] See for example, E. A. Ankumah, The African Commission on Human and Peoples' Rights (1996) p. 176.

[33] Guardian Newspaper v. Attorney-General of the Federation Suit No. M/139/84.

[34] Tlakula F. P., Activities as Special Rapporteur on Freedom of Expression and Access to Information Activity Report of the Special Rapporteur on Freedom of Expression in Africa $41^{\text {st }}$ Ordinary Session, Accra - Ghana 16 - 30 June, 2007.

[35] Communication 101/93, Civil Liberties Organisation in respect of the Nigeria Bar Association v. Nigeria, Eight Annual Activity Report, para. 16.

[36] See C. Heyns (ed.), Human Rights Law in Africa Vol. 2, Leiden: Martinus Nijhoff Publishers, 2004, 89.

[37] Fifth Annual Activity Report: $11^{\text {th }}$ Ordinary Session of the African Commission on Human and Peoples' Rights, 28.

[38] See Human Rights Watch, Suppressing Dissent: Human Rights Abuses and Political Repression in Ethiopia's Roomier Regime, May 2005, vol. 17, no. 7 (A);

[39] See for example, D'Sa, R. M., “The African Charter on Human and Peoples' Rights: Problems and Prospects for Regional Action", (1981-83) 10 Australian Yearbook of International Law, Australian National University, pp. 101-130; Arthur, Lewis W, "Beyond African Dictatorship: The Crisis of a One-Party State" (1965) 25 (2) Encounter; Msekwa, P. "The Doctrine of the One-Party State in Relation to Human Rights and the Rule of Law" in ICJ, Human Rights 33-55.

[40] See further Minority Rights Group International (1997) "World Directory of Minorities." London Minority Rights Group International; Wippman, D (Ed) (1998) International Law and Ethnic Conflict, Cornell University Press, U.S.A.; Packer, J (2000): "The Origin and Nature of the Lund Recommendations on the Effective Participation of National Minorities in Public Life" Helsinki Monitor, 11; G. Pentassuglia, "Towards a Jurisprudential Articulation of Indigenous Land Rights" (2010) 21 European Journal of International Law; Rehman, J (2000) The Weakness in the International Protection of Minorities, Kluwer International, The Hague, London, Boston; and Steven Wheatley (1999) "Minority Rights, Power Sharing and the Modern Democratic State", in Peter Cumper and Steven Wheatley (eds.) Minority Rights in the "New" Europe, 199. 
Adjei, W.E., (2019)

Re-assessment of "claw-back" clauses in the enforcement of human and peoples' rights in Africa

[41] Mbondenyi, M. K. \& Sifuna, N. W., "A Review of Procedural and Jurisdictional Challenges in Enforcing International Human Rights Law under the African Charter Regime" (2006) Bepress Legal Series; Mugwanya, G.W., "Realizing Universal Human Rights Norms Through Regional Human Rights Mechanisms: Reinvigorating the African System" (1999) 10 Indiana International \& Comparative Law Review 35; Neumayer, E. “Does International Human Rights Treaties Improve Respect for Human Rights?”, (2005) 49, Journal of Conflict Resolution 939.

[42] For further information about the African Commission on Human and Peoples' Rights, see Dresso SA “The Jurisprudence of the African Commission on Peoples' Rights of the African Charter", available at:

http://www.chr.up.ac.za/about/introduction.html. [Accessed on 16/6/2010]

[43] Human Development Report 2000 Background Paper (produced by the UN Development Programme). Some countries, such as South Africa (which acceded to the Charter in 1996) have called for tougher enforcement mechanisms, which could include turning the present Commission into a working court. See also Manisuli Seenyonj (ed.), The African Regional Human Rights System: 30 Years after the African Charter on Human and Peoples' Rights (Martinus Nijhoff Publishers 2012); Obiora Okafor, The African Human Rights System and International Institutions (Cambridge University Press, 2007); Makau wa Mutua, "The African Human Rights System in a Comparative Perspective," 3 Rev. Afr. Comm. Hum. \& Peoples’ Rights 5, 7 (1993).

[44] C.A. Odinkalu, "The Individual Complaints Procedures of the African Commission on Human and Peoples' Rights: A Preliminary Assessment" (1998) 8 Transnational and Contemporary Problems 359, 382. Nmehielle Obisienuwo Orlu, The African Human Rights System: Its Laws, Practice, and Institutions, Martinus Nijhoff Publishers, The Hague/London/New York, 2001, 165. See also Welch C. E., The African Commission on Human and Peoples' Rights: A Five-Year Report and Assessment, (1992) Vol. 14 (1) Human Rights Quarterly 43, 46.

[45] Institute for Human Rights and Development in Africa v. Republic of Angola (2008) AHRLR 43 (ACHPR 2008). For further illustration, John K. Modise v. Botswana, African Commission on Human and Peoples' Rights, Communication No. 97/93 (1997); John K. Modise v. Botswana, African Commission on Human and Peoples' Rights, Communication No. 97/93 (2000).

[46] Ibid., Communication No. 292/2004, para. 63.

[47] See for example, Samantha Power and Graham Allison, "Realizing Human Rights: Moving from Inspiration to Impact" (Palgrave Macmillan 2000); Christof Heyns, "The African Regional Human System: The African Charter" [2003-2004] 108 Penn St L Rev $679,695$.

[48] 101/93 Civil Liberties Organisation (in respect of the Nigerian Bar Association) v. Nigeria, $8^{\text {th }}$ Annual Activity Report [in Compilation 1994-2001, IHRDA, Banjul 2002, pp. 200-202, para. 16.

[49] Communication 105/93, 128/94, 130/94, 152/96, Media Rights Agenda and Constitutional Rights Project v. Nigeria, Decision taken at the $24^{\text {th }}$ Session, October 1998 , Comment by Rachel Murray, South African Journal of Human Rights, vol. 17, part 1, 2001. See further Loveness Mapuva, "Negating the Promotion of Human Rights Through "Claw- 
Adjei, W.E., (2019)

Re-assessment of "claw-back" clauses in the enforcement of human and peoples' rights in Africa

Back" Clauses in the African Charter on Human and Peoples' Rights" (2016), Vol. 51, International Affairs and Global Strategy.

[50] Viljoen F. (2007:349)

[51] Ouguergouz O., (supra note 8) 2003:606

[52] Ibid., para. 66

[53] Communication no. 297/2005, Scanlen \& Holderness v. Zimbabwe, Adopted during the $6^{\text {th }}$ Extra-Ordinary Session of the ACHPR, Banjul, The Gambia, April 2009, para, 68. Notably, Zimbabwe is a State Party to the African Charter on Human and Peoples' Rights (ACHPR), which guarantees freedom of expression under Article 9.

[54] Ibid. para. 119

[55] Ibid. para. 115

[56] Ibid. para. 112

[57] Ibid.

[58] Legal Resources Foundation v. Zambia, Communication No. 211/98 (2001)

[59] Amnesty International v. Zambia (2000) AHRLR 325 (ACHPR 1999), para. 41

[60] African Charter, Article 12 (2)

[61] Banda Case, para. 50

[62] ARTICLE 19 v. Eritrea, African Commission on Human and Peoples' Rights: Communication no. 275/2003 (2007). For further reading, see Mosope Fagbongbe, Top Court Talk: Twenty Years of Communication before the African Commission on Human and Peoples' Rights: Article 19 v. Eritrea, November 30, 2007; ARTICLE 19, A Model Freedom of Information Law (London: 2001), available at: http://www.article19.org/pdfs/. ; ARTICLE 19, The Public's Right to Know: Principles on Freedom of Information Legislation (London: June 1999), available at:

http://www.article19.org/pdfs/standards/righttoknow.pdf .

[63] Eritrea: ARTICLE 19 v. Eritrea (2007) AHRLR 73 (ACHPR 2007), para. 90.

[64] Ibid. para. 91

[65] See for example, communication 101/93 Civil Liberties Organisation (in respect of the Bar Association) v. Nigeria (2000) AHRLR 186 (ACHPR 1995), para. 16: and communication 212/98, Amnesty International v. Zambia, para. 50.

[66] See Communications 147/95 and 149/96, Jawara v. The Gambia, paras. 57-59.

[67] Hansungule M (2004:3)

[68] African Charter, Article 27 (2)

[69] See for example, Mauritanian Political Parties Case, para. 80: ("closely linked" to freedom of expression and right to association invoked together).

[70] Once the prima facie violation (or 'limitation') has been established, the onus to justify the limitation falls on the respondent state (see for example, Nigerian Media Case, para. 77 ('in this case, the government did not offer any explanation......').

[71] Nigerian Media Case, para. 68; Prince Case, para. 43.

[72] See for example, The Punch Newspapers (Proscription and Prohibition from Circulation) Decree No. 7 of 1994.

[73] Communications 140/94, 141/94, 145/95 (joined), Constitutional Rights Project and Others v. Nigeria (2000) AHRLR 227 (ACHPR 1999) (13 ${ }^{\text {th }}$ Annual Activity Report): ('Nigerian Newspapers Proscription Case'), para. 44. See also the Prince Case, para. 44. 
Adjei, W.E., (2019)

Re-assessment of "claw-back" clauses in the enforcement of human and peoples' rights in Africa

[74] Labiyi v. Anretiola: 1992

[75] The following remarks were delivered by Sir Shridath Ramphal in opening the conference on Rights and Democracy in Canada and the United Kingdom, University of Warwick, 17 May 1997. 